\title{
PENGARUH PRODUK DOMESTIK REGIONAL BRUTO (PDRB) TERHADAP PENDAPATAN ASLI DAERAH (PAD) DI KABUPATEN/KOTA PROVINSI SUMATERA BARAT
}

\author{
Rukmi Juwita, Annisa Widia \\ D4 Akuntansi Keuangan, Politeknik Pos Indonesia \\ rukmijuwita@poltekpos.ac.id, annisawidiaa@gmail.com
}

\begin{abstract}
ABSTRAK
Pertumbuhan ekonomi merupakan gambaran hasil kerja pemerintah daerah untuk mesejahterakan masyarakat dan bisa diartikan sebagai proses kenaikan pendapatan suatu daerah. Provinsi Sumatera Barat memiliki sumber pendapatan yang berbeda salah satunya adalah pendapatan asli daerah, oleh karena itu penelitian ini bertujuan untuk membuktikan pengaruh Produk Domestik Regional Bruto terhadap Pendapatan Asli Daerah di Kabupaten/Kota Provinsi Sumatera Barat. Metode yang digunakan dalam penelitian adalah kuantitatif asosiatif, data yang digunakan pada penelitian ini adalah data sekunder yang bersumber dari ringkasan APBD pendapatan Kabupaten/Kota tahun anggaran 2018-2019 yang berasal dari website resmi Badan Pusat Statistik (BPS). Analisis data yang digunakan adalah menggunakan analisis regresi linier sederhana. Penelitian ini menggunakan 16 sampel dan data. Alat analisis yang digunakan pada penelitian ini adalah uji normalitas data, korelasi product moment, regresi linier sederhana, koefisien determinasi, dan uji t. Hasil penelitian ini menunjukkan bahwa produk domestik regional bruto tidak berpengaruh terhadap pendapatan asli daerah di Kabupaten/Kota Provinsi Sumatea Barat.

Kata kunci: Produk Domestik Regional Bruto (PDRB), Pendapan Asli Daerah (PAD)
\end{abstract}

ABSTRACT

Economic growth is a description of the work of local governments for the welfare of society and can be interpreted as the process of increasing the income of an area. West Sumatra Province has different sources of income, one of which is local revenue, therefore this study aims to prove the effect of Gross Regional Domestic Product on Regional Original Income in Regency / City of West Sumatra Province. The method used in the research is associative quantitative, the data used in this study is secondary data sourced from the summary of the District / City APBD revenue for the 2018-2019 fiscal year which comes from the official website of the Central Statistics Agency (BPS). The data analysis used is simple linear regression analysis. This study used 16 samples and data. The analytical tools used in this research are data normality test, product moment correlation, simple linear regression, coefficient of determination, and test. The results of this study indicate that the gross regional domestic product has no effect on local revenue in the Regency / City of West Sumatea Province.

Keywords: Gross Regional Domestic Product (PDRB), Regional Original Income (PAD) 


\section{PENDAHULUAN}

Indonesia saat ini terdari dari 34 provinsi yang tersebar, provinsi tersebut terdiri dari Kabupaten maupun Kota dimana Kabupaten maupun Kota memiliki peraturan daerah yang berbeda untuk mengatur dan mempermudah dalam menjalankan kegiatan pemerintah, maka dari itu Pemerintah Indonesia mengeluarkan peraturan sebagai acuran pemerintah daerah. Sesuai dengan isi dari Perundang-undangan pasal 18, Pemerintah daerah provinsi, daerah kabupaten, dan kota mengatur dan mengurus sendiri urusan pemerintahan menurut asas otonomi dan tugas pembantuan. Pemerintah daerah mejalankan otonomi seluasluasnya, kecuali urusan pemerintahan yang oleh dengan Undang-Undang sebagai urusan pemerintah pusat.

Pendapatan Daerah terdiri atas Pendapatan Asli Daerah (PAD), Pendapatan Transfer, dan Pendapatan lain-lain yang sah. Berdasarkan Undang-Undang Republik Indonesia Nomor 33 Tahun 2004 Tentang Pemerintah Pusat dan Pemerintah Daerah. Pendapatan Asi Daerah (PAD) mencakup pajak daerah, retribusi daerah, hasil pengelolaan kekayaan daerah yang dipisahkan, dan pendapatan lain-lain yang sah. Sumber ekonomi yang terdapat didaerah harus dikelola dengan baik dan bertanggung jawab, yang berarti hasilnya harus maksimal untuk meningkatkan pertumbuhan perekonomian dan menghasilkan pendapatan serta kemandirian untuk daerah.

Pertumbuhan ekonomi suatu daerah merupakan perubahan ekonomi yang bertahap menuju keadaan yang lebih baik. Pertumbuhan ekonomi merupakan gambaran hasil kerja pemerintah daerah untuk mesejahterakan masyarakat dan bisa diartikan sebagai proses kenaikan pendapatan suatu daerah. Setiap daerah akan saling berlomba untuk meningkatkan perekonomiannya. Perekonomian bisa disebutkan menjalani perkembangan apabila aktivitas ekonomi mendapati proses dari setiap tahun berikutnya. Kawasan yang perekonominya memberikan hasil yang positif akan memungkinkan peningkatan terhadap PAD, perkembangan perekonomian bisa dihitung menggunakan PDRB, PDRB dipakai untuk membuktikan hasil kerja perekonomian kawasan. Produk Domestik Regional Bruto maupun agregatnya turunannya disajikan dengan menggunakan atas dasar harga konstan. Dikatakan harga konstan karena penilaian yang digunakan didasarkan pada harga satu tahun dasar tertentu. Harga kontan adalah yang dilakukan terhadap produk barang dan jasa yang dihasilkan ataupun yang dikonsumsi pada harga tetap disatu tahun dasar.

Pertumuhan ekonomi di daerah akan berdampak pada hasil pendapatan daerah, jika pertumbuhan ekonominya baik maka akan berdampak positif terhadap pedapatan daerah dan jika pertumbukan ekonominya negatif maka akan berdampak buruk terhadap pendapatan daerah. Pertumbuhan ekonomi suatu daerah dapat dilihat dari tinggi atau rendahnya nilai Produk Domestik Regional Bruto (PDRB) yang diperoleh daerah. Pertumbuhan ekonomi dihitung berdasarkan harga konstan tahun yang bersangkutan terhadap tahun sebelumnya. Penelitian ini dibutuhkan untuk saat ini dikarenakan jika nilai produk domestik regional bruto mengalami penurunan terus menerus akan berdampak buruk terhadap pendapatan daerah di Provinsi Sumatera Barat. Pada tahun 2018-2019, Provinsi Sumatera Barat mengalalami kenaikan keaikan produk domestic regional bruto. Berikut sekilas mengenai produk domestic regional bruto periode 20182019.

Tabel 11 Produk Domestik Bruto per Kapita di Daerah Kabupaten/Kota Provinsi Sumatra Barat Tahun 2019 Berdasarkan Harga Konstan 2010

\begin{tabular}{|l|c|c|}
\hline \multicolumn{2}{|c|}{ Kabupaten/Kota } & $\begin{array}{c}\text { PDRB Harga Konstan 2010 } \\
\text { PDRB Harga Konstan 2010 }\end{array}$ \\
\hline Jumlah Sumatera & $30.477,76$ & 2019 \\
Barat & & $31.669,59$ \\
\hline \multicolumn{2}{|l}{ Sumber: (BPS Sumatera, 2019) }
\end{tabular}

Sumatera Barat pada tahun 2018-2019 memiliki total hasil yang berbeda, yaitu pada tahun 2019 yang mengalami kenaikan dengan jumlah Rp 31. 669,59. Hal ini dikarenakan adanya kenaikan di beberapa sektor perekonomian di Kabupaten/Kota Provinsi Sumatera Barat. Hasil tersebut merupakan potensi yang menguntungkan bagi pemerintah daerah untuk mencapai kenaikan Pendapatan Asli Daerah (PAD). (mitianus Murib, 2018) 
Penelitian yang kedua dilakukan oleh Hijri Juliansyah dan Sulkadria tahun 2018 dengan judul Pengaruh Total Penduduk dan PDRB Terhadap Pendapatan Asli Daerah (PAD) Kabupaten Simuelue. Dalam penelitian ini, peneliti dapat menyimpulkan bahwa Produk Domestik Regional Bruto (PDRB) berpengaruh secara parsial terhadap Pendapatan Asli Daerah (PAD) di Kabupaten Simuelue. (Juliansyah \& Sulkadria, 2018).

Yang ketiga dilakukan oleh Ryan Perwira dan Vitayanti Fatlah pada tahun 2018 dengan judul Pengaruh PDRB, Pengaluaran Pembangunan dan Jumlah Penduduk Produktif Terhadap Pendapatan Asli Daerah di Kabupaten/Kota di Sulawesi Selatan. Pada penelitian ini, peneliti dapat menyimpulkan bahwa Produk Domestik Regional Bruto (PDRB) berpengaruh positif dan signifikan terhadap Pendapatan Asli Daerah di Sulawesi Tengah, berdasarkan hasil uji-t yang telah terbukti. (Perwira et al., 2018)

Yang kelima penelitian yang dilakukan oleh Afifah Ariyanti, Fitri Yetti, dan Noegrahini Lastiningsih pada tahun 2018 dengan judul Pengaruh Produk Domestik Regional Bruto (PDRB), Jumlah Penduduk dan Pajak Hotek Terhadap Pendapatan Asli Daerah (PAD). Penelitian ini menyimpulkan bahwa produk domestic regional bruto, jumlah penduduk dan pajak hotel berpengaruh signifikan positif terhadap pendapatan asli daerah. (Wiji Lestari, 2017)

Penelitian selanjutnya dilakukan oleh Idham Nur Iman, Ima Amaliah dan Meidy Haviz pada tahun 2019 dengan judul Pengaruh Jumlah Penduduk, PDRB, dan Belanja Daerah Terhadap Pendapatan Asli Daerah di Kabupaten Bandung tahun 2000-20017. Pada penelitian ini, peneliti dapat menyimpulkan bahwa Produk Domestik Regional Bruto (PDRB) secara parsial berpengaruh signifikan dan elastis terhadap Pendapatan Asli Daerah (PAD) di Kabupaten Bandung. (Iman et al., 2019)

Yang selanjutnya dilakukan oleh Caesar Muslim, Syahrir Mallongi, dan Zainuddin Rahman pada tahun 2019 dengan judul Pengaruh PDRB, Jumlah Penduduk, dan Tingkat Inflasi Tehadap Pendapatan Asli Daerah Kota Kendari. Pada penelitian kali ini dapat disimpulkan bahwa hasil dari pengolahan data menunjukkan bahwa PDRB tidak berpengaruh signifikan terhadap peningkatan PAD. (Caesar Muslim, 2019)

Berdsarkan latar belakang dan penelitian terdahulu, maka rumusan masalah pada penelitian ini sebagai berikut:

1. Bagaimana Produk Domestik Regional Bruto (PDRB) di Kabupaten/Kota Provinsi Sumatera Barat ?

2. Bagaimana Pendapatan Asli Daerah (PAD) di Kabupaten/Kota Provinsi Sumatera Barat?

3. Bagaimana Pengaruh Produk Domestik Regional Bruto (PDRB) terhadap Pendapatan Asli Daerah (PAD) di Kabupaten/Kota Provinsi Sumatera Barat?

\section{KAJIAN PUSTAKA}

Produk Domestik Regional Bruto (PDRB)

Menurut Badan Pusat Statistik (BPS) mengartikan bahwa Produk Domestik Regional Bruto (PDRB) harga konstan merupakan cara yang dilakukan terhadap produk barang dan jasa yang dihasilkan ataupun yang di konsumsi pada harga tetap di satu tahun dasar dan bertujuan untuk mengukur pertumbuhan ekonomi. (Produk Domestik Regional Bruto Provinsi Sumatera Barat, 2019)

Pendapatan Asli Daerah (PAD)

Pendapatan Asli Daerah (PAD) adalah salah satu pendapatan yang diperoleh daerah sesuai dengan peraturan, hal ini tercantum dalam Undang-Undang Nomor 33 Tahun 2004 Tentang Perimbangan Keuangan Antara Pemerintah Pusat dan Pemerintah Daerah pada saat ini telah berganti menjadi UndangUndang Republik Indonesia Nomor 23 Tahun 2014 Tentang Pemerintah Daerah. Pendapatan Asli Daerah (PAD) meliputi pajak daerah, retribusi daerah, hasil pengelolaan kekayaan daerah yang dipisahkan, dan pendapatan lain-lain yang sah yang sudah tercantum dalam Peraturan Pemerntah Nomor 12 Tahun 2019 Tentang Pengelolaan Keuangan.

Menurut Nurkholis dan Moh. Khusaini (2019:24) menjelaskan bahwa Pendapatan Asli Daerah (PAD) adalah bagian dari pendapatan daerah yang bersumber dari potensi daerah itu sendiri yang dipungut berdasarkan peraturan daerah tersebut sesuai dengan peraturan perundang-undangan yang berlaku. (Nurkholis \& moh. Khusaini, 2019) 


\section{METODE PENELITIAN}

\section{Jenis Penelitian}

Metode yang digunakan pada penelitian ini adalah metode kuantitatif data sekunder dengan menggunakan hipotesis asosiatif. Menurut Sugiono (Sugiyono, 2017:23). "Data kuantitatif adalah data yang berbentuk angka, atau data kualitatif yang diangkakan (skoring)". Dalam penelitian ini juga menggunakan hipotesis asosiatif. Menurut Sugiono (Sugiyono, 2017:89) "hipotesis asosiatif adalah pertanyaan yang bermaksud dugaan mengenai hubungan antara dua variabel atau lebih".

\section{Teknik Pengumpulan Data}

Dalam penelitian ini sumber data yang digunakan adalah data sekunder yang didapat dari hasil laporan ringkasan APBD tahun 2018-2019 melalui web site resmi Badan Pusat Statistik (BPS) Sumatera Barat, dan menggunakan teknik sampling yang dilakukan dengan cara menentukan populasi dan sampel.

\section{Teknik Sampling}

Dalam peneliian ini, teknik yang digunakan yaitu teknik non-probability sampling dengan metode purposive sampling. Menurut (Sugiyono, 2017:84) non-probability sampling adalah "teknik pengambilan sampel yang tidak memberikan peluang atau kesempatan sama bagi setiap unsur atau anggota populasi untuk dipilih menjadi sampel." Sedangkan purposive sampling adalah Sugiono (2016:85) menjelaskan "purposive samling adalah teknik penentuan sampel dengan pertimbangan tertentu."

Adapun kriteria yang dijadikan sampel yaitu:

1. Laporan realisasi penerimaan pemerintah daerah di kabupaten/kota provinsi Sumatera Barat

2. Laporan realisasi penerimaan pemerintah daerah pada kabupaten/kota yang mengalami penurunan pendapatan asli daerah lebih dari Rp 20.000.000

\section{Populasi dan Sampel}

Populasi pada penelitian ini adalah 19 (sembilan belas) Kabupaten/Kota di Provinsi Sumatera Barat dan sampel yang digunakan dalam penelitian ini menjadi 16 (enam belas) Kabupaten/Kota di Provinsi Sumatera Barat tahun periode 2018-2019 yang memenuhi kriteria pada pengambilan sampel. Berikut ini sampel 16 (enam belas) sampel yang digunakan yang telah memenuhi kriteria:

Tabel 12 Sampel Penelitian Kabupaten/Kota Provinsi Sumatera Barat

\begin{tabular}{|l|l|l|l|}
\hline \multicolumn{1}{|c|}{ No } & \multicolumn{1}{|c|}{ Kabupaten/Kota } & No & \multicolumn{1}{|c|}{ Kabupaten/Kota } \\
\hline 1. & Kepulauan Mentawai & 9. & Solok Selatan \\
\hline 2. & Pesisir Selatan & 10. & Dharmasraya \\
\hline 3. & Solek & 11. & Kota Solok \\
\hline 4. & Sjiunjung & 12. & Sawah Luntu \\
\hline 5. & Tanah Datar & 13. & Bukittinggi \\
\hline 6. & Agam & 14. & Payalcumbuh \\
\hline $7 .$. & Lima Puluh Kota & 15. & Pariaman \\
\hline 8. & Pesaman & 16 & Padang Pariaman \\
\hline
\end{tabular}

\section{Teknik Analisis Data}

Pada penelitian ini, analisis yang dipergunakan terdiri dari: Uji Normalitas Data, Korelasi Product Moment, Regresi Linier Sederhana Koefisien Determinasi, dan Uji Hipotesis T.

\section{Uji Normalitas Data}

Menurut Sujarweni (V. Wiratna Sujarweni, 2016) menjelaskan bahwa "uji normalitas bertujuan untuk mengetahui distribusi data dalam variabel yang akan digunakan dalam penelitian. Data yang baik dan layak digunakan dalam penelitian adalah data yang memiliki distibusi normal." Sedangkan menurut 
Ghozali (2016:154) menyaakan bahwa "Uji normalitas data dapat dilakukan dengan menggunakan One Sample Kolmogorov Smirnov, yaitu dengan ketentuan:"

a. Jika nilai signifikan lebih besar sama dengan (>) 0,05 maka data tersebut berdistribusi normal

b. Jika nilai signifikan lebih kecil (<) 0,05 maka data tersebut berdistribusi tidak normal.

\section{Korelasi Product Moment}

Menurut Sugiono (Sugiyono, 2017:228) menjelaskan bahwa "teknik ini digunakan untuk mencari hubungan dan membuktikan hipotesis hubungan dua variabel bila data kedua variabel berbentuk interval atau ratio, dan sumber data dari dua variabel atau lebih tersebut adalah sama". Adapun rumus dari korelasi product momen adalah sebagai berikut:

\section{Regresi Linier Sederhana}

Menurut Sugiono (Sugiyono, 2017:261) menyatakan regresi linier didasarkan pada hubungan fungsional ataupun kausal satu variabel independen dengan satu variabel dependen.

\section{Koefisien Determinasi}

Menurut Sugiono (Sugiyono, 2017:231) menjelaskan bahwa koefisien determinasi, yang besarnya adalah kuadrat dari koefisien korelasi $\left(\mathrm{r}^{2}\right)$. Koefisien ini disebut koefisien penentu, karena varians yang terjadi pada variabel dependen dapat dijelaskan melalui varians yang terjadi pada variabel independen. Koefisien determinasi dihitung dengan menguadratkan koefisien korelasi yang telah ditemukan dan selanjutnya dikalikan $100 \%$.

\section{Uji T}

Menurut Sugiono (Sugiyono, 2017:230) menyatakan "untuk menguji signifikansi hubungan, yaitu apakah hubungan yang ditemukan berlaku untuk seluruh populasi, maka perlu diuji signifikannya".

\section{HASIL PENELITIAN DAN PEMBAHASAN \\ Hasil Penelitian \\ Uji Normalitas Data}

Dari hasil uji normalitas data yang telah dilakukan menunjukkan variabel yang mempunyai nilai Asymtotic Significated (2-tailed) sebesar 0,099 yang dimana angka tersebut menunjukkan bahwa angka tersebut lebih besar dari nilai 0,05 yang dinyatakan angka tersebut berdistribusi normal.

\section{Analisis Korelasi Product Moment}

Dari hasil pengolahan data korelasi product moment dengan menggunakan software spss 25.0 maka nilai korelasi product moment antara variabel Product Domestik Regional Bruto terhadap Pendapatan Asli Daerah sebesar -0,257. Angka -0,257 ini menunjukkan bahwa terjadi hubungan yang sangat rendah dikarenakan berada di rentan $0,00-0,199$.

\section{Analisis Regresi Linier Sederhana}

Pengolahan diatas diketahui bahwa hasil dari nilai R sebesar -0,257. Dari hasil tersebut diperoleh angka yang menjelaskan bahwa pengaruh produk domestic regional bruto terhadap pendapatan asli daerah, sebagai berikut:

$\mathrm{Y}=\mathrm{a}+\mathrm{bX}$

$\mathrm{Y}=9472334107.287+(-1187.013) \mathrm{X}$

1. Jika variabel (X) Produk Domestik Regional Bruto nilainya adalah 0, maka nilai variabel (Y) Pendapatan Asli Daerah adalah konstanta sebesar 9472334107.287

2. Jika nilai variabel $(\mathrm{X})$ Produk Domestik Regional Bruto naik 1 ribu rupiah, maka akan menurunkan Pendapatan Asli Daerah sebesar -1187.013.

\section{Analisis Koefisien Determinasi}


Berdasarkan tabel diatas menunjukkan bahwa presentase pengaruh variabel $\mathrm{x}$ terhadap variabel $\mathrm{y}$ sebesar 6,6 \% sedangkan sisanya 93,4\% dipengaruhi oleh faktor lain yang tidak termasuk dalam penelitian ini.

\section{Uji T}

Dari hasil pengolahan data diatas, menunjukkan bahwa -t hitung sebesar -1,530 dengan derajat kebebasan sebesar 30 (n-k-1 yaitu 32-1-1) dan pengujian dua pihak (two tails test) dengan taraf signifikansi 5\% atau 0,05 maka diperoleh - $t$ tabel sebesar -2,042 sehingga angka tersebut menunjukkan nilai $-\mathrm{t}$ hitung > -t tabel $(-1,530>-2,042)$, maka Ho diterima dan Ha ditolak, artinya tidak terdapat pengaruh signifikan antara produk domestic regional bruto terhadap pendapatan asli daerah di kabupaten/kota provinsi Sumatera Barat. Berikut ini secara visual daerah penerimaan Ho dan penolakan Ha dapat dilihat pada gambar berikut ini:

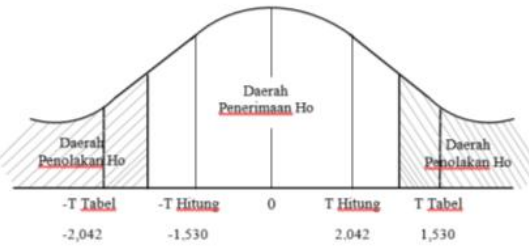

Gambar 1 Hasil Uji T

\section{PEMBAHASAN}

\section{Bagaimana Produk Domestik Regional Bruto di Kabupaten/Kota Provinsi Sumatera Barat}

Produk Domestik Regional Bruto yang mengalami penurunan pada tahun 2019 terjadi pada daerah Padang Pariaman sebesar 9.391,87 hal ini dikarenakan karena menurunnya menurunnya dari sector usaha sedangkan yang mengalami kenaikan tertinggi berada di daerah Padang Panjang sebesar 1.903,41 yang disebabkan oleh kenaikan dari sector perdagangan yang menjadi sumber utama.

\section{Produk Domestik Bruto Per Kapita di Daerah Kabupaten/Kota Provinsi Sumatra Barat Tahun 2019 Berdasarkan Harga Konstan 2010 (Ribu Rupiah)}

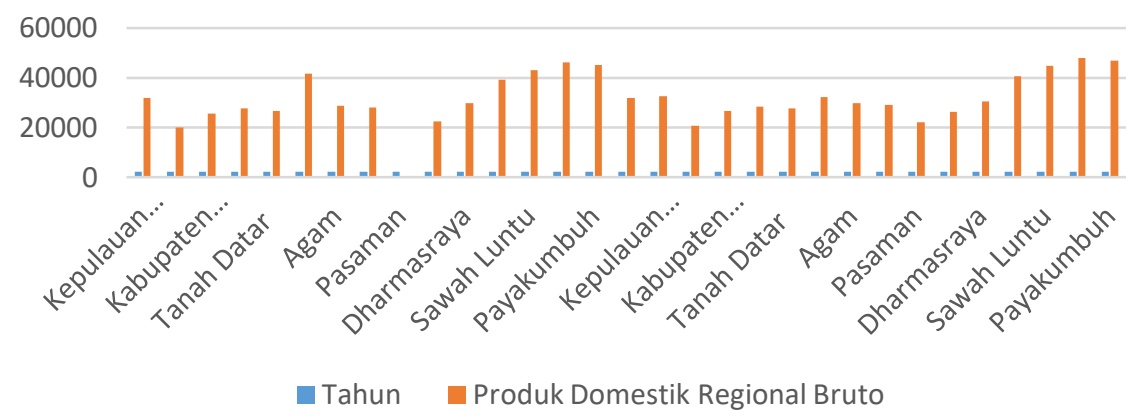

\section{Pendapatan Asli Daerah di Kabupaten/Kota Provinsi Sumatera Barat}

Pada penentuan pendapatan asli daerah di Kabupaten/Kota Provinsi Sumatera Barat tahun anggaran 2018-2019 yang dimana pendapatan asli daerah mengalami penurunan cukup signifkan. Alasan peneliti mnggunakan data tersebut karena untuk mengetahui daerah yang mengalami kenaikan atau penurunan. Kenaikan atau penurunan pada tahun 2018-2019 terdebut dapat dilihat grafik berikut: 


\section{Pendapatan Asli Daerah Kabupaten/Kota Provinsi \\ Sumatera Barat Tahun Anggaran 2018-2019 (Ribu \\ Rupiah)}

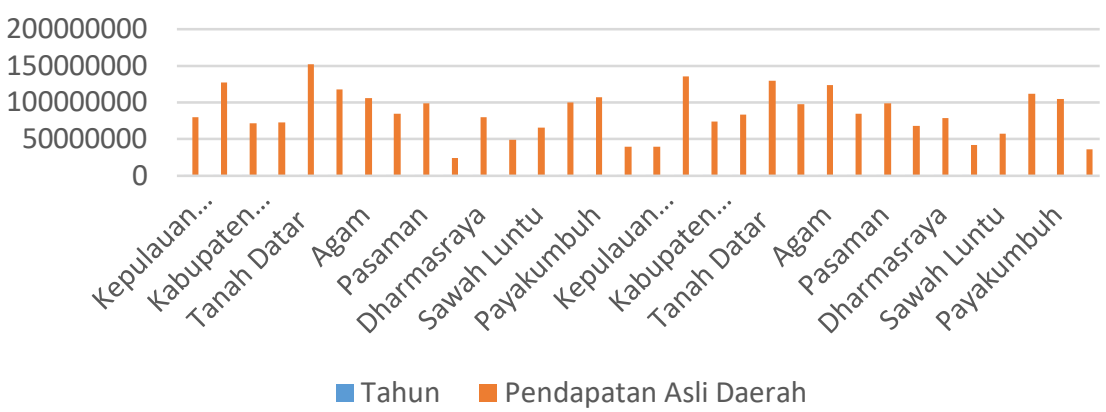

Menurut grafik diatas dapat dilihat bahwa kenaikan pendapata asli daerah terdapat di daerah Tanah Datar pada tahun 2018 sebesar Rp 152.110.032,00 hal ini dikarenakan lebih mendorong pendapatan daerah melalui pajak dan yang mengalami penurunan pendapatan asli daerah berada di daerah Kepulauan Mentawai pada tahun 2019 sebesar Rp 4.063.395,07. Hal ini dikarenakan berbagai persoalan, salah satunya adalah masalah konflik di pulau Nyang-nyang.

\section{Pengaruh Produk Domestik Regional Bruto Terhadap Pendapatan Asli Daerah}

Pada hasil uji normalitas data menunjukkan besarnya Asymptotic Significanted (2-tailed) sebesar 0,099. Angka tersebut menunjukan bahwa probabilitas $>0,05$ dan menyatakan bahwa data yang digunakan berdistribusi normal.

Dalam hasil analisis koefisien korelasi product moment, besarnya koefisien korelasi antara variabel produk domestic regional bruto terhadap pendapatan asli daerah dari penghitungan yaitu sebessar $-0,257$. Angka $-0,257$ ini menunjukkan bahwa terjadi hubungan yang sangat rendah dikarenakan berada di rentan $0,00-0,199$.

Analisis regresi linier sederhana memperoleh persamaan 9472334107.287 + (-1187.013) X yang menunjukkan jika product domestic regional bruto dinaikkan 1 ribu rupiah akan maka akan penurunkan pendapatan asli daerah sebesar -1187,013.

Hasil koefisien determinasi menjelaskan bahwa product domestic regional bruto terhadap pendapatan asli daerah berpengaruh hanya sebesar 6,6\% sedangkan sisanya 93,4\% dipengaruhi oleh faktor lain yang tidak termasuk dalam penelitian ini.

Dari hasil pengujian hipotesis uji t diketahui bahwa -t hitung untuk variabel produk domestic regional bruto adalah sebesar -1.530 dengan derajat kebebasan sebesar 30 (n-k-1 yaitu 32-1-1) dan pengujian dua pihak dengan taraf signifikansi 5\% atau 0,05 maka diperoleh -t tabel sebesar -2,042 sehingga -t hitung lebih kecil dari -t tabel $(-1,530>-2,042)$ dengan demikian maka Ho diterima dan Ha ditolak. Artinya tidak terdapat pengaruh antara produk domestic regional bruto terhadap pendapatan asli daerah di kabupaten/kota provinsi Sumatera Barat. Tidak berpengaruhnya produk domestic regional bruto terhadap pendapatan asli daerah dikarenakan produk domestic regional bruto ada yang mengalami penurunan yang drastis yang berakibat terhadap pendapatan asli daerah.

\section{Kesimpulan}

1. Produk Domestik Regional Bruto di Kabupaten/Kota Provinsi Sumatera Barat mengalami penurunan pada tahun 2019 terjadi pada daerah Padang Pariaman sedangkan yang mengalami kenaikan tertinggi berada di daerah Padang Panjang

2. Pendapatan Asli Daerah di Kabupaten/Kota Provinsi Sumatera Barat kenaikan pendapata asli daerah terdapat di daerah Tanah Datar pada tahun 2018 dan yang mengalami penurunan pendapatan asli daerah berada di daerah Kepulauan Mentawai pada tahun 2019 
3. Produk Domestik Regional Bruto Terhadap Pendapatan Asli Daerah tidak berpengaruh di kabupaten/kota provinsi Sumatera Barat.

\section{DAFTAR PUSTAKA}

Badan Pusat Statistik Provinsi Sumatera Barat. (2019). Provinsi Sumatera Barat Dalam Angka Sumatera (B. P. S. P. S. Barat (ed.); Cetakan 1). BPS Provinsi Sumatera Barat.

BPS. (2018). Perkembangan Ekonomi Sumatera Barat (B. P. S. B. Bidang Neraca Wilayah dan Analisis

Statistik (ed.); CV. Graphi). Badan Pusat Statistik Provinsi Sumatera Barat.

(https://sumbar.bps.go.id/, t.thn.)

http://peraturan.bpk.go.id

Iman, 1Idham Nur, Amaliah, I., \& Haviz, M. (2019). Pengaruh Jumlah Penduduk, PDRB dan Belanja Daerah terhadap Pendapatan Asli Daerah (PAD) di Kabupaten Bandung Tahun 2000-2017. Prosiding Ilmu Ekonomi, 5(2), 386-393.

Juliansyah, H., \& Sulkadria. (2018). Pengaruh total penduduk dan produk domestik regional bruto terhadap pendapatan asli daerah kabupaten simeulue. Ekonomi Regional Unimal, 01(02), 58-64.

Nurkholis, \& moh. Khusaini. (2019). penganggaran sektor publik (cetakan pe, pp. 1-203). UB Press.

Perwira, R., Ridwan, \& Fattah, V. (2018). PENGARUH PDRB, PENGELUARAN PEMBANGUNAN DAN JUMLAH PENDUDUK PRODUKTIF TERHADAP PENDAPATAN ASLI DAERAH DI KABUPATEN/KOTA DI SULAWESI TENGAH Ryan. E Jurnal Katalogis, 6(2), 1-15.

http://ppid.sumbarprov.go.id

Sugiyono. (2017). Statistika untuk Penelitian. Bandung: Penerbit Alfabeta. In Jurnal Akuntansi. https://doi.org/10.24912/ja.v21i1.137

Undang-Undang Nomor 33 Tahun 2004 Tentang Perimbangan Keuangan Antara Pemerintah Pusat dam Pemerintah Daerah

Undang-Undang Nomor 28 Tahun 2009 Tentang Pajak Daerah dan Retribusi Daerah

Undang-Undang Nomor 23 Tahun 2014 Tentang Pemerintah Daerah

V.Wiratna Sujarweni. (2016). Kupas Tuntang Penelitian Akuntansi dengan SPSS (Mona (ed)) 